\title{
Prognostic value of serum soluble ST2 in professional athletes Valor pronóstico de ST2 soluble en suero en deportistas profesionales
}

*Madina Baurzhan, **Salim Berkinbayev, ***Kuat Abzaliyev, *Zhanar Andassova, ***Yrysbubu Anvarbekova, ****Symbat Abzaliyeva, ****Karashash Absatarova, **Shynar Tanabayeva, *****Gulnar Rakhimbekova, **Ildar Fakhradiyev

*Kazakhstan's School of Public Health (Republic of Kazakhstan), **S.D. Asfendiyarov Kazakh National Medical University (Republic of Kazakhstan), ***I.K. Akhunbaev Kyrgyz state medical academy (Republic of Kyrgystan), ****Al Farabi Kazakh National University (Republic of Kazakhstan), *****NJSC «Astana Medical University» (Republic of Kazakhstan)

\begin{abstract}
Background:The predictive value of serum soluble ST2 (SST2) biomarker for diagnostics of cardiovascular pathologies is still poorly understood as well as the role of psychological stress on the risk of heart disease. Aim:This study aimed at determining the diagnostic significance of the sST2 level in athletes involved in speed-strength sports. In addition, stress as a risk factor for the development of cardiovascular pathology was assessed and analysed as well. Methods: A prospective study on Greco-Roman wrestlers was carried out at the Centre for Sports Medicine and Rehabilitation (Almaty, Republic of Kazakhstan).All participants $(\mathrm{n}=30$ ) were males aged 20 to 34 years. The control group consisted of volunteers $(\mathrm{VO})(\mathrm{n}=30)$. Anthropometric and hemodynamic parameters of athletes were studied along with electrocardiography (ECG) and ECG tests. The sST2 level was determined before (BT) and immediately after (AT) training. The stress level was determined using The Perceived Stress Scale10 (PSS-10). Results: The average age of the athletes was $26.57 \pm 3.6$ years. The total training experience was $14.57 \pm 4.02$ years. According to the ECG data, minor deviations from the norm (13.3\%) and an abnormal ECG (33.3\%) were identified. Echo-CG data showed «moderate» and «pronounced changes» in 23.3\% and 53.3\% of cases, respectively.The sST2 level ofVO (337.1 $\pm 61.8 \mathrm{pg} / \mathrm{mL}$ ) was lower than that of BT (548.1 $\pm 32.6 \mathrm{pg} / \mathrm{mL})(\mathrm{pd} \gg 0.001)$. The sST2 level of AT, it was significantly higher $(830.01 \pm 71.6 \mathrm{pg} / \mathrm{mL})$ than BT (p d» 0.001). The average and high level of stress among athletes was in $43.3 \%$ and $56.7 \%$ of cases, respectively. Stress increased the likelihood of developing distinctly abnormal ECG $(\mathrm{OR}=1.06,95 \% \mathrm{CI} 1.01-1.08 ; \mathrm{p}=0.02)$. The stress level showed a positive correlation with the sST2 level $(\mathrm{r}=0.752, \mathrm{p}=0.01)$. The sST2 concentration and categorical echocardiography data demonstrated a dependent positive correlation $(r=0.6, p=0.01)$. Conclusions: Athletes' sST2 levels exceeded thresholds both before and after training. Moreover, the relationship between an increase in sST2 levels and abnormal ECG abnormalities and a high level of stress in athletes was determined. sST2 concentration was associated with cardio-pulmonary stress triggered by the cumulative exercise dose as well as with lifelong psychological stress. Our findings indicate that the elevated sST2 concentrations in athletes could be used as the predictive value. However, clinical relevance and results validity require further intensive studies.
\end{abstract}

Keywords: solubleST2; biomarker; heart hypertrophy; stress; athletes.

Resumen. Antecedentes: El valor predictivo del biomarcador ST2 soluble en suero (sST2) en la enfermedad cardiovascular aún no se conoce bien, así como el papel del estrés psicológico en el riesgo de enfermedad cardiovascular. Objetivos: Este estudio tuvo como objetivo determinar la importancia diagnóstica del nivel de sST2 en atletas involucrados en deportes de velocidad-fuerza. Además, también se evaluó y analizó el estrés como factor de riesgo para el desarrollo de patología cardiovascular. Métodos: Se llevó a cabo un estudio prospectivo sobre luchadores grecorromanos en el Centro de Medicina y Rehabilitación del Deporte (Almaty, República de Kazajstán). Todos los participantes ( $\mathrm{n}=30$ ) eran hombres de entre 20 y 34 años. El grupo de control estaba formado por voluntarios $(\mathrm{VO})(\mathrm{n}=30)$. Se estudiaron los parámetros antropométricos y hemodinámicos de los atletas junto con las pruebas de electrocardiografía (ECG). El nivel de sST2 se determinó antes (BT) e inmediatamente después (AT) del entrenamiento. El nivel de estrés se determinó utilizando la Escala de Estrés Percibido-10 (PSS-10). Resultados: La edad promedio de los deportistas fue de 26,57 \pm 3,6 años. La experiencia de formación total fue de 14,57 \pm 4,02 años. Según los datos del ECG, se identificaron desviaciones menores de la norma (13,3\%) y un ECG anormal (33,3\%). Los datos de Echo-CG mostraron cambios «moderados» y «pronunciados» en el 23,3\% y el 53,3\% de los casos, respectivamente. El nivel de sST2 del grupoVO (337,1 $\pm 61,8 \mathrm{pg} / \mathrm{mL})$ fue menor que el de BT (548,1 $\pm 32,6$ $\mathrm{pg} / \mathrm{mL}$ ) (p d» 0,001),). El nivel de sST2 en AT fue significativamente mayor (830.01 $\pm 71.6 \mathrm{pg} / \mathrm{mL}$ ) que en BT (p d»0.001). El nivel medio y alto de estrés entre los deportistas fue del 43,3\% y el 56,7\% de los casos, respectivamente. El estrés aumentó la probabilidad de desarrollar un ECG claramente anormal $(\mathrm{OR}=1,06 ; \mathrm{IC}$ del 95\%: 1,01-1,08; $\mathrm{p}=0,02)$. El nivel de estrés mostró una correlación positiva con el nivel de sST2 $(\mathrm{r}=0,752, \mathrm{p}=0,01)$. La concentración de sST2 y los datos de la ecocardiografía categórica demostraron una correlación positiva dependiente $(\mathrm{r}$ $=0,6, p=0,01)$. Conclusión: Los niveles de sST2 de los atletas excedieron los umbrales tanto antes como después del entrenamiento. Además, se determinó la relación entre un aumento en los niveles de sST2 y anomalías anormales del ECG y un alto nivel de estrés en los atletas. La concentración de SST2 se asoció con el estrés cardiopulmonar desencadenado por la dosis acumulativa de ejercicio, así como con el estrés psicológico de por vida. Nuestros hallazgos indican que las concentraciones elevadas de sST2 en los atletas pueden usarse como valor predictivo. Sin embargo, se requieren más estudios.

Palabras clave: soluble ST2; biomarcador; hipertrofia cardíaca; estrés; atletas.

Fecha recepción: 22-02-21. Fecha de aceptación: 21-07-21

Ildar Fakhradiyev

fakhradiyev.i@kaznmu.kz 


\section{Introduction}

The assessment of specific biomarkers is critical for the prediction of the risk of developing heart disease (Albert, 2011). One of these biomarkers is the ST2 receptor for interleukin 1, also known as the interleukin1 receptor-like 1 (IL1RL-1) (Pascual-Figal \& Januzzi, 2015). Previous studies have demonstrated the importance of determining the level of sST2 as a biomarker of various pathological processes (Kakkar \& Lee, 2008). It has been shown that the concentration of sST2 in the blood increases in many inflammatory diseases (Mueller \& Jaffe, 2015). For instance, Weinberg et al. (2003) showed that the levels of circulating serum sST2 might be employed for the assessment of patients with chronic severe heart failure.

Taking into account that symptoms of cardiovascular pathology can be hidden due to adaptive mechanisms, heart diseases can develop asymptomatically (Lee, Chandel, \& Simon, 2020; Nakamura \& Sadoshima, 2018; Shevchenko, Bohmat, Holovko, \& Demianenko, 2019). The pathways leading from biomechanical overload to cardiac remodeling are of primary clinical importance, but this process remains not fully defined (Weinberg et al., 2002).

Therefore, there is a need to expand the choice of diagnostic tools for the timely detection of cardiac disorders and the prevention of possible complications (Kovacs \& Baggish, 2016). Aengevaeren et al. (2019) showed that the change in the concentration of sST2 in the blood could be used as a predictor of cardiovascular disease in runners (before and after exercise). However, it must be noted that this study did not compare the level of this biomarker in people who are not involved in sports.

Given the fact that there is a different classification of physical activity depending on the type of sport (Garcia, Muñiz, Rodriguez, \& Suarez, 2016; Holfelder, Klotzbier, Eisele, \& Schott, 2020; Howley, 2001; Schnell, 2019), it can be assumed that changes in the cardiovascular system of athletes may significantly vary (Barbas et al., 2011). In turn, the concentration of sST2 in various types of sports can also differ. In this regard, prolonged physical activity in athletes can trigger an increase in the size of the heart by 10-20\% (Sharma, Merghani, \& Mont, 2015). Athletes engaged in strength sports develop pure concentric hypertrophy of the left ventricle leading to an increase in both absolute and relative wall thickness and a significant increase in the diameter of the left ventricle (Pluim, Zwinderman, van der Laarse, \& van der Wall, 2000). Apart from that, it should be noted that cardiac fibroblasts and cardiomyocytes produce circulating ST2 in response to stress and overload (Weinberg et al., 2002).

In fact, focussing on the development of strength can lead to exceeding the recommended limit of physical activity, and developing possible complications (Kovacs \& Baggish, 2016).

Unfortunately, not only excessive physical activity in athletes (Gustafsson, Sagar, \& Stenling, 2017) is a risk factor for cardiac disorders. It has been shown that psychological distress during competitions is an important negative factor as well (Villarreal-Angeles, Rodriguez Vela, Tapia Martínez, Gallegos Sanchez, \& Moncada-Jimenez, 2021). Hence, the constant fear of failure and loss also potentiates the impact of psychoemotional stress on physical health (Proietti et al., 2011). The negative role of emotional stress as a trigger for the development of acute coronary disorders was described by Wilbert - Lampen et al. (2008). It was demonstrated that the incidence of cardiovascular complications was doubled not only among athletes, but also among spectators (during the sports matches).

It has been shown that stress may be the most important factor, but it is not the only a cause for the development of cardiac complications in people with pre-existing cardiovascular disorders (Rafanelli, Roncuzzi, Ottolini, \& Rigatelli, 2007). However, it is worth noting that psycho-emotional stress is still one of the main factors in the development of cardiovascular diseases (Steptoe \& Kivimäki, 2012) and damage of cardiomyocytes (Alevizos, Karagkouni, Panagiotidou, Vasiadi, \&Theoharides, 2014). In this regard, the purpose of this study was to identify the diagnostic significance of the sST2 level in athletes engaged in sports (focused on 'speed-strength'). In addition, the study aimed at the assessment of stress as a risk factor for the development of pathology of the cardiovascular system.

\section{Materials and Methods}

\section{Participants}

This is a prospective non-randomized study with the participation of 30 male athletes aged 20-34 years (Greco-Roman wrestling) with an experience of 5 years or more continuous training and competition. The study was conducted on the basis of the Centre for Sports Medicine and Rehabilitation (Almaty, Republic of Kazakhstan). During preparation, athletes adhered to a standard diet in accordance with standard time ranges 
corresponding to normal competitions.

As a control group (VO), the study included 30 volunteers aged 20-34: young people who are not involved in professional sports.

\section{Ethical issues}

The study was approved by the Ethical Committee of Kazakh Medical University of Continuing Education, Almaty, Kazakhstan. All athletes were fully informed about the experimental procedures, the possible risks and benefits associated with their participation in the study.

\section{General information}

Depending on their age, the study participants were sub-divided into 3 age categories: 20-24 years old, 2529 years old and 30-35 years old. The athletes possessed the following official sports qualifications, including Master of Sports (MS), Master of Sports of International Class (MSMK) and Honoured Master of Sports (ZMS). The level of systolic blood pressure (SBP) and diastolic blood pressure (DBP) at rest was determined according to the ACC / AHA guidelines (Drawz et al., 2020). The pulse rate at rest (Alexis, 2010), level of $\mathrm{VO}_{2 \max }$ (Hawkins, Raven, Snell, Stray-Gundersen, \& Levine, 2007), weight and height (SECA, model M20812, Hamburg, Germany), body mass index (BMI) were calculated according to the standard formula (Wan Nudri, Wan Abdul Manan, \& Mohamed Rusli, 2009).

\section{ECG Data Analysis}

Before the ECG study, athletes kept a horizontal position for 5 minutes, to adapt to environmental conditions. The study was carried out in the morning time at an air temperature of at least $22^{\circ} \mathrm{C}$ (Sharma et al., 2017). ECG analysis was performed in 12 leads, recording speed $50 \mathrm{~mm} / \mathrm{s}$, in the supine position, using the BTL Cardiopoint ECG C600 (UK) apparatus. ECG data were analysed at the Research Institute of Cardiology and Internal Medicine (Almaty, Kazakhstan) by two independent cardiologists and divided into three subgroups (normal, mildly abnormal, and abnormal) according to a previous study (Koch, Cassel, Linné, Mayer, \& Scharhag, 2014).

\section{Echocardiographic Data Analysis}

Echocardiography was performed using an ACUSON S1000 ultrasound machine of the HELX Evolution series (Germany). In accordance with the recommendations of the American Society of
Echocardiography (Churchill et al., 2020) the following parameters were determined: LV volume, mass, relative wall thickness, mitral flow velocity, tissue Doppler velocity, LAV, LVEF. Left atrial deformity and global longitudinal LV deformity were measured using 2D speckle tracking software (Cameli et al., 2017).

\section{Plasma / Serum IL1RL1 (ST2) Determination}

Blood samples were taken on an empty stomach, according to standard protocol rules (Giavarina \& Lippi, 2017), from the antecubital vein $(10 \mathrm{ml}), 30$ minutes before exercise (BT) and within two hours after exercise (AT). Blood samples were placed in test tubes (Ayset, Turkey) and centrifuged at $300 \mathrm{~g}$ for $10 \mathrm{~min}$, then frozen, and stored at $-70{ }^{\circ} \mathrm{C}$ for the analysis (Boisot et al., 2008). The sST2 concentration was determined using a commercial human sST2 ELISA kit (Westang Biotech Co., Shanghai, China) according to the manufacturer's instructions (Chen et al., 2018).

It has been shown that an intensive trainings can affect the occurrence of haematological changes in blood ( for example, on the level of haemoglobin, haematocrit) (Santos, 2018). Hence, to calculate changes in plasma volume by determining the levels of haemoglobin and haematocrit (to assess the degree of dehydration), $2 \mathrm{ml}$ of venous blood was additionally taken before and after training for evaluation according to the previously described method (Dill \& Costill, 1974).

The analysis was carried out in a certified (ISO 15189 2015) scientific clinical diagnostic laboratory of the Scientific Research Institute of FPM named after B. Atchabarov (Almaty, Kazakhstan).

\section{Characteristic of physical activity}

The standard training of the study participants consisted of a set of 3-hour exercises for sequential execution. In addition, daily training included outdoor walking, warm-up for 15 minutes before the main set of exercises. The main routine of physical activity consisted of several types of exercises related to general and special physical training. In terms of the complex of general physical training, exercises were performed on gym machines (1.5 hours), such as a horizontal bar (4 sets x 25 reps), parallel bars (4 sets x 30 reps), and exercises to strengthen the muscles of the back (4 sets $\mathrm{x} 20$ reps), the press (4 sets $\mathrm{x} 25$ reps) and jumping out with a pancake (4 sets $\mathrm{x} 20$ reps). According to the special physical training exercises, the athletes practiced wrestling techniques (1.5 hours). 


\section{Evaluation of level of stress}

The level of perceived stress and subjective perception of the level of tension in athletes was assessed using the «The Perceived Stress Scale-10» («PSS-10») questionnaire. The PSS-10 questionnaire consists of 10 questions and determines how stressful people think the previous month of their life (Anwer, Manzar, Alghadir, Salahuddin, \& Abdul Hameed, 2020). Answer options are scored on a 5-point Likert scale (0-4), with scores as follows: 4: never, 3: rarely, 2: sometimes, 1: often, 0: always. It should be noted that items 4, 5, 7 and 8 were calculated positively. An overall score of 13 corresponds to normal stress levels, and a score of 20 or higher indicates 'high-stress' levels requiring therapeutic intervention (Cohen, 1988). Thus, the results obtained can be interpreted as follows: normal score (0-13), average score (14-20) and high score: $(>20)[33]$. In our study, we used an adapted version of the PSS-10 questionnaire in Russian language. The choice of version 10 of the PSS questionnaire in comparison with other available versions such as PSS-7 and PSS-14 was justified by the fact that the analysis of previous studies shows higher psychometric properties of the PSS-10 questionnaire (Lee, 2012).

\section{Statistical analysis}

Statistical analysis was performed using SPSS Statistics 25 programme (SPSS Inc., Chicago, Illinois, USA). Data normality was verified using the Kolmogorov-Smirnov test and the homogeneity of variances (Levene test) were confirmed ( $\mathrm{p}>$.05). Once the normal distribution was confirmed, studying groups were compared using the unpaired and paired Student s $t$ test. The statistical significance was set at $p<0.05$.

\section{Results}

The average age of athletes was $26.57 \pm 3.6$ years (Table 1). By age groups, athletes aged 20-24 years accounted for $33 \%(n=10), 25-29$ years were in $50 \%$ $(\mathrm{n}=15), 30-35$ years was $16.7 \%(\mathrm{n}=5)$. The total training experience was $14.57 \pm 4.02$ years. According to anthropometric data, the average weight and height were equal to $80.03 \pm 18.9 \mathrm{~kg}$ and $174.02 \pm 9.5 \mathrm{~cm}$, respectively, the BMI was $26.03 \pm 3.49 \mathrm{~kg} / \mathrm{m}^{2}$. The median plasma volume change was $0 \%$ (-5\% to $4 \%$ ).

The SBP level was $119.67 \pm 7.64 \mathrm{~mm} \mathrm{Hg}$, the DBP was $79.50 \pm 6.9 \mathrm{~mm} \mathrm{Hg}$, the pulse rate was $65.6 \pm 9.5$ beats / min., the average maximum oxygen uptake was $67.3 \pm 4.2 \mathrm{ml} / \mathrm{kg} / \mathrm{min}$. In the sports category, the overwhelming majority of athletes' $n=19(63.3 \%)$ were Master of International Sports, $\mathrm{n}=9(30 \%)$ were Master of Sports and $\mathrm{n}=2(6.7 \%)$ were Honoured Master of Sports.

\begin{tabular}{|c|c|c|c|c|}
\hline \multicolumn{5}{|c|}{$\begin{array}{l}\text { Table } 1 \\
\text { General characteristics of research participants }\end{array}$} \\
\hline Data $(\mathrm{N}-30)$ & Average & SD & Min & Max \\
\hline Age & 26.57 & 3.569 & 20 & 34 \\
\hline $20-24$ n(\%) & \multicolumn{4}{|c|}{$10(33)$} \\
\hline $25-29 \mathrm{n}(\%)$ & \multicolumn{4}{|c|}{$15(50)$} \\
\hline $30-35$ n(\%) & \multicolumn{4}{|c|}{$5(16.7)$} \\
\hline Experience (years) & 14.5 & 4.0 & 10 & 22 \\
\hline Weight (before training) & 80.0 & 18.9 & 57 & 127 \\
\hline Weight (after training) & 78.2 & 17.5 & 56 & 127 \\
\hline Height & 174.0 & 9.5 & 160 & 201 \\
\hline Body Mass Index (kg/ m²) & 26.0 & 3.4 & 20.7 & 35.2 \\
\hline Systolic blood pressure (rest) & 119.6 & 7.6 & 105 & 140 \\
\hline Diastolic blood pressure (rest) & 79.5 & 6.9 & 70 & 90 \\
\hline Pulse (rest) & 65.6 & 9.4 & 55 & 89 \\
\hline $\mathrm{VO}_{2 \max }(\mathrm{ml} / \mathrm{kg} / \mathrm{min})$ & 67.3 & 4.2 & 58 & 72 \\
\hline \multicolumn{5}{|c|}{ Sports qualifications $\mathrm{n}(\%)$} \\
\hline Master of Sports & \multirow{2}{*}{\multicolumn{4}{|c|}{$\begin{array}{r}9(30) \\
19(63.3)\end{array}$}} \\
\hline Master of International Sports & & & & \\
\hline Honoured Master of Sports & \multicolumn{4}{|c|}{$2(6.7)$} \\
\hline
\end{tabular}

ECG data showed that, $\mathrm{R}$ or $\mathrm{S}$ wave $25-29 \mathrm{~mm}$ in $\mathrm{n}$ $=21(70 \%)$ cases, $\mathrm{R}$ or $\mathrm{S}$ wave equal to $30-34 \mathrm{~mm}$ in $\mathrm{n}$ $=2(6.6 \%)$ cases, $R$ or $S$ wave $35 \mathrm{~mm}$ and $30^{\circ} \mathrm{d} » \mathrm{QRS}$ axise» $110^{\circ}$ in $\mathrm{n}=3(10 \%)$ cases, sinus bradycardia $<$ $60 \mathrm{bpm}$ in $\mathrm{n}=12(40 \%)$ cases, flat $/$ tall T wave $\mathrm{n}=3$ $(10 \%)$ and $Q$ wave $2-3 \mathrm{~mm} \mathrm{n}=4(13.3 \%)$, left bundle branch block (LBBB) only n $=1(3.3 \%)$ case. Analysis of ECG data (Table 2) for three subgroups (normal, with minor deviations and abnormal) demonstrated a normal ECG in $\mathrm{n}=16(53.4 \%)$, with minor deviations in $\mathrm{n}=4(13.3 \%)$ and in $\mathrm{n}=10(33.3 \%)$ cases are abnormal.

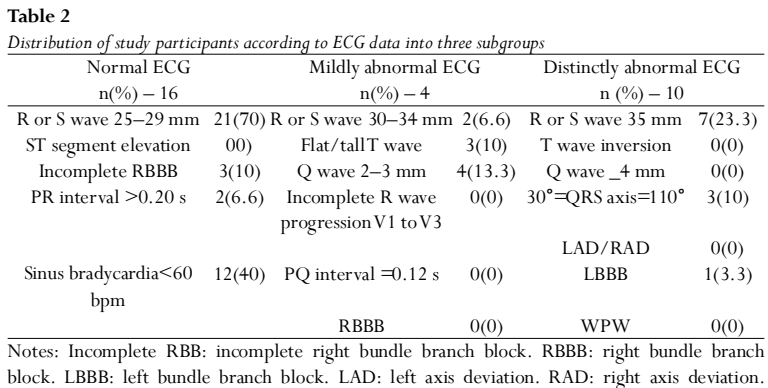
block. LBBB: left bundle branch block. LAD: left axis deviation. RAD: right axis deviation. WPW: Wolff-Parkinson-White syndrome. Values presented as n (\%);

The results of echocardiography in athletes (Table $3)$ showed the mean left atrial diameter (LAD) was $38.9 \pm 6.2 \mathrm{ml}$, the size of the interventricular septum (IVS) was $1.1 \pm 0.19 \mathrm{~cm}$, the thickness of the posterior wall $(\mathrm{PW})$ was $1.03 \pm 0.15 \mathrm{~cm}$, and the diameter of the aortic root $(\mathrm{AO})$ was $3.04 \pm 0.46 \mathrm{~cm}$. The ratio of left ventricular diastolic diameter / body surface area / (LV EDD / BSA) was $48.2 \pm 20.6 \mathrm{~mm} / \mathrm{cm} 2$, left ventricular diastolic diameter was $4.9 \pm 0.28 \mathrm{~cm}$. EDW and ESV were $117.6 \pm 15.58 \mathrm{~cm}$ and $41.6 \pm 7.3 \mathrm{~cm}$, respectively. The EF percentage was $64.9 \pm 3.08 \%$. 
The average left ventricular mass (LV mass) was 188.27 $\pm 37.5 \mathrm{gr}$, and the LVM was $105.7 \pm 26.3 \mathrm{gr} / \mathrm{m}^{2}$. The E-wave / A-wave (E / A) ratio was $1.29 \pm 0.26$, and the relative wall thickness (RWT) was $0.38 \pm 0.07$.

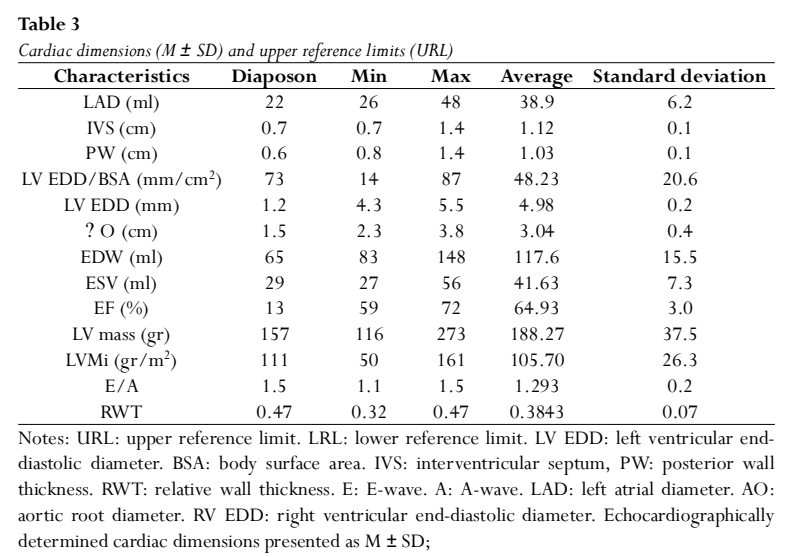

\section{sST2 level in the blood sample}

To determine the level of sST2 expression in blood serum, first the serum sST2 level in VO at rest and in athletes in BT was analysed. The results showed (Figure 1) that sST2 levels were significantly higher $\left(p d^{\mathrm{TM}}\right.$ $0.001)$ in the BT $548.1 \pm 32.6 \mathrm{pg} / \mathrm{mL}$ group than in the VO $337.1 \pm 61.8 \mathrm{pg} / \mathrm{mL}$. Serum sST2 level for AT $830.01 \pm 71.6 \mathrm{pg} / \mathrm{mL}$ was significantly higher than BT ( $p \mathrm{~d}^{\mathrm{TM}}$ 0.001) (Figure 2).

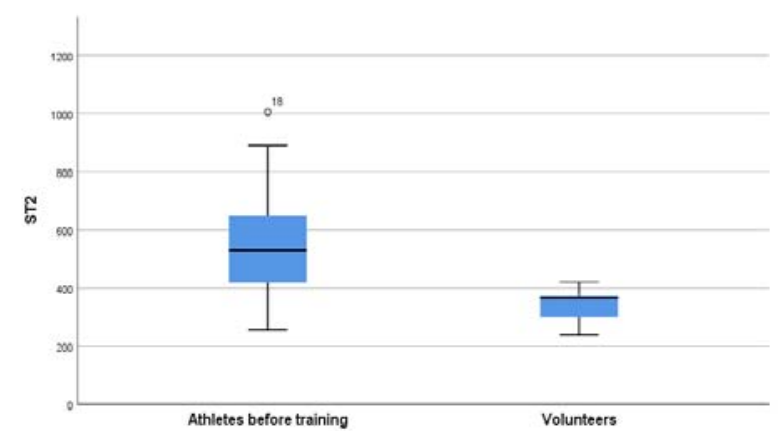

Figure 1

Analysis of serum sST2 levels in volunteers $(\mathrm{VO})(\mathrm{n}=30)$, athletes before training $(\mathrm{BT})(\mathrm{n}=30)$ Data presented as median (IQR); $p=0.001 ; \mathrm{BT}$ compared to VO;

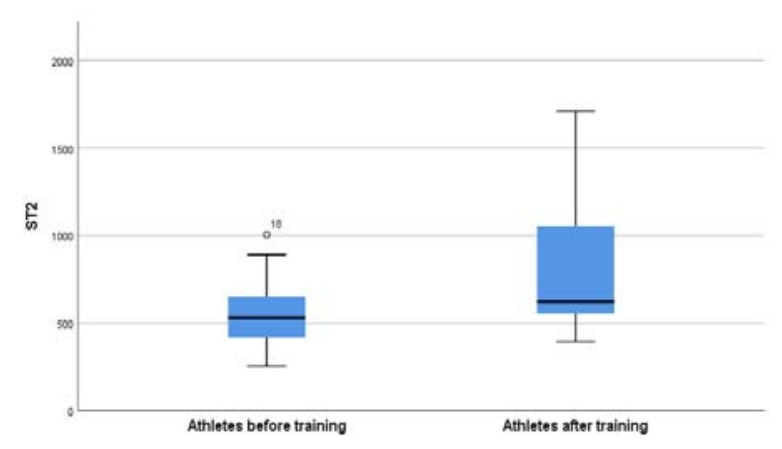

Figure 2

Analysis of serum sST2 levels in athletes before (BT) $(\mathrm{n}=30)$ and athletes after training (AT) $(\mathrm{n}=30)$. Data presented as median (IQR), $\mathrm{p}=0.001, \mathrm{BT}$ compared to AT;
Evaluation of the results of perceived stress PSS-10 (Table 4) showed that the absence of athletes with normal stress levels, $n=13(43.3 \%)$ was at an average level and $n=17$ (56.7\%) experienced a high level of stress. The average score on the stress scale was $24.0 \pm$ 6.7 .

In the age category 20-24 years old $n=4(30.8 \%)$ athletes scored $14-20$ points, above 20 points in this age category were determined in $\mathrm{n}=6(35.3 \%)$ participants. Athletes aged 25-29 received 14-20 points in $\mathrm{n}=7$ $(53.8 \%)$ cases, and a high level of stress was identified in $\mathrm{n}=8(47.1 \%)$ respondents.

\begin{tabular}{|c|c|c|c|c|}
\hline \multirow[t]{2}{*}{ Characteristics } & \multicolumn{4}{|c|}{ Score PSS-10 n(\%) } \\
\hline & $0-13$ & $14-20$ & 20and more & $\mathrm{M} \pm \mathrm{SD}$ \\
\hline Stress scale & $0(0)$ & $13(43.3)$ & $17(56.7)$ & $24.0 \pm 6.7$ \\
\hline 20-24years & $0(0)$ & $4(30.8)$ & $6(35.3)$ & $24.4 \pm 6.1$ \\
\hline 25-29years & $0(0)$ & $7(53.8)$ & $8(47.1)$ & $23.8 \pm 6.7$ \\
\hline 30-35years & $0(0)$ & $2(15.4)$ & $3(17.6)$ & $23.6 \pm 9.0$ \\
\hline Physical exertion* & \multicolumn{4}{|c|}{$13.50 \pm 5.368$} \\
\hline Resistance* & \multicolumn{4}{|c|}{$10.50 \pm 2.776 *$} \\
\hline
\end{tabular}

Notes: PSS-10:The Perceived Stress Scale-10. * Data presented M \pm SD;

In univariate analysis, perceived stress increased the likelihood of prevalence of Distinctly abnormal ECG $(\mathrm{OR}=1.06,95 \%$ CI 1.01-1.08; $p=0.02)$.

The assessment of the stress level depending on the three components of the ECG study (normal, with minor deviations and abnormal) indicated that the level of perceived stress was significantly higher in athletes with distinctly abnormal ECG $23.9 \pm 1.2$ versus 19.7 $\pm 0.7(p=0.05)$ in Mildly abnormal and against 17.4 $\pm 1.2(p=0.001)$ in Normal ECG.

The sST2 concentration and categorical echocardiography data demonstrated a dependent positive correlation $(r=0.6, p=0.01)$ The level of the stress showed a positive correlation with the sST2 level $(\mathrm{r}=0.752, p=0.01)$ (Figure 3).

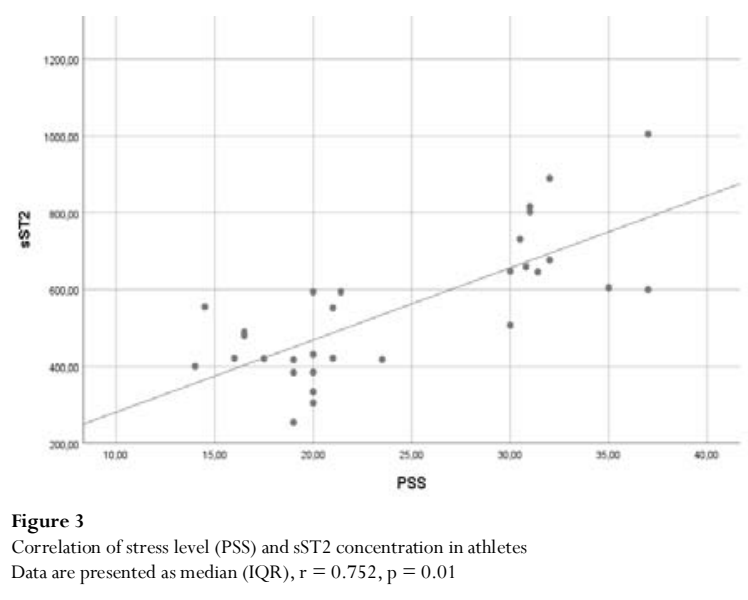

\section{Discussion}

To the best of our knowledge, this is the first study 
on the assessment of the concentration of sST2 as a possible indicator of the development of heart disorders in athletes engaged in strength sports. The results obtained showed a comparatively high level of sST2 in combat athletes before training in comparison with the control group. In addition, we observed an increase in the concentration of sST2 after training. Our data are consistent with previous reports, where sST2 scores were above cut-off values in $48 \%$ of professional runners before the start of a marathon and in 92\% after a marathon run (Aengevaeren et al., 2019).

It has previously been shown that young athletes under 35 years old, in comparison with their peers who are not athletes, had an increased risk of sudden death due to cardiovascular diseases (Corrado, Basso, Rizzoli, Schiavon, \& Thiene, 2003). Adaptive mechanisms that develop during intense physical exertion lead to functional and structural changes in the cardiovascular system (Dickhuth, Röcker, Mayer, König, \& KorstenReck, 2004). Moreover, the thickness of both the septum and the posterior wall of the heart increases to the same extent as the internal volume (van de Schoor et al., 2016). The ratio of mass to volume and, therefore, the maximum systolic wall stress remains constant, in contrast to the pathological forms of hypertrophy (Dickhuth et al., 2004). These findings indicate the need for dynamic monitoring of the state of the cardiovascular system of athletes.

It should be noted that compared to other biomarkers such as natriuretic peptides and troponins (Aimo et al., 2019; Berg, Ruff, \& Morrow, 2021; Cediel et al., 2021; Perrone et al., 2020; Wallentin et al., 2021), sST2 concentration is independent on the age, renal function or body mass index (Dieplinger et al., 2009). These findings were confirmed in our study as well.

The pathophysiological explanation for the increase in the concentration of SST2 in the blood serum can be linked to the susceptibility of the sST2 gene to the mechanical stress in cardiac myocytes (Weinberg et al., 2003). However, the question of whether sST2 is an indicator of structural changes in the myocardium remains controversial. Some researchers have come to the conclusion that the concentration of sST2 in nonischemic heart failure reflects the level of hemodynamic stress, but the pathogenic processes in the myocardium (Broch et al., 2015). In addition, sST2 concentration is dependent on endothelial cells, but not in cardiomyocytes (Demyanets et al., 2013).

Apart from that, the concentration of sST2 level can be high in other various pathologies as well (Socrates et al., 2010; Tajima et al., 2007). However, the concentration of sST2 is associated with cardiac fibrosis, and some experiments have shown that sST2 has been expressed in mechanically stressed cardiomyocytes (Weinberg et al., 2002).

According to the PSS-10 questionnaire, all athletes had a medium or high level of stress, of which $57.6 \%$ of athletes with scores above 20 on this scale had indirect indications for therapeutic assistance. Cardiovascular changes caused by stress associated with the secretion of catecholamine are similar to those observed during exercise (Gavrilovic, Spasojevic, \& Dronjak, 2012; Hammadah et al., 2017; Sarvasti et al., 2020; Webb, Rosalky, McAllister, Acevedo, \& Kamimori, 2017).

In the situation when the heart rate and myocardial contractility increase, peripheral vasoconstriction leads to a significant elevation of arterial pressure (Shephard, 1997). In addition, it is necessary to note the important role of not only activation of the sympathetic nervous system in response to stress factors, but also a decrease in cholinergic activity. It can result in an increase in cortisol levels and a decrease in glucocorticoid sensitivity. In turn, it may lead to vascular complications causing cardiovascular pathologies (Wirtz \& von Känel, 2017).

In a previous study, echocardiographic findings did not show any pathological correlation between elevated sST2 levels and left ventricular function (Quick et al., 2015), its diameter or mass, but this relationship was found out in another study (Shah, Chen-Tournoux, Picard, van Kimmenade, \& Januzzi, 2009). In the present study, distinctly abnormal changes in the ECG were detected, which had a statistically significant relationship not only with an increase in sST2 concentration $(p=0.01)$, but also with the level of stress perception $(p=0.01)$. The results obtained indicate the importance of the sST2 concentration in the diagnosis of the cardiovascular system; however, due to its narrow specificity, it is not possible to assert the full role of increasing the sST2 concentration as a predictor of cardiovascular pathology.

The stress associated with participating in multiple sports tournaments can also potentiate the chances of developing cardiovascular disorders, although this influence is largely indirect (Ogilvie et al., 2016). Therefore, there is a need to pay attention to psychotherapeutic support as one of the important components of preventive measures. Our findings indicate that regular monitoring (biochemical and psychological) of the level of stress in athletes can help to optimize the physical activity in the early stages (González-Boto, Salguero, Tuero, González-Gallego, \& 
Márquez, 2008).

\section{Study limitations}

This prospective study has some limitations, including a small study sample. Further randomized controlled studies with a longer observational period of changes in a relatively large sample of athletes are needed to interpret the full mechanism of the development of adaptive processes and structural changes in cardiac tissue during the stress. It should encompass an accurate determination of the relationship between stress and the level of sST2 concentration in sportsmen.

\section{Conclusions}

Our data showed that athletes' sST2 levels exceeded thresholds both before and after exercise. Moreover, the relationship of increased sST2 levels with abnormal ECG abnormalities and high-stress levels in athletes was determined. The sST2 concentration is associated with cardiopulmonary stress induced by the cumulative exercise dose as well as psychological stress. The role of elevated sST2 level in athletes under the stress requires further intensive studies.

\section{Funding}

This research received no external funding. The work was carried out within the Ph.D. dissertation framework.

\section{Acknowledgments}

The authors express their gratitude for the administrative and technical support provided by the S.D. Asfendiyarov Kazakh National Medical University.

\section{Conflicts of Interest}

The authors declare no conflict of interest.

\section{References}

Aengevaeren, V. L., Van Kimmenade, R., Hopman, M., VAN Royen, N., Snider, J. V., Januzzi, J. L., . . . Eijsvogels, T. (2019). Exercise-induced Changes in Soluble ST2 Concentrations in Marathon Runners. Medicine and science in sports and exercise, 51(3), 405410. doi.org/10.1249/MSS.0000000000001806
Aimo, A., Januzzi, J. L., Bayes-Genis, A., Vergaro, G., Sciarrone, P., Passino, C., \& Emdin, M. (2019). Clinical and Prognostic Significance of sST2 in Heart Failure JACC Review Topic of the Week. Journal of the American College of Cardiology, 74(17), 2193-2203. doi.org/10.1016/j.jacc.2019.08.1039

Albert, M. A. (2011). Biomarkers and heart disease. Journal of Clinical Sleep Medicine, 7(5 Suppl), S9-S11. doi.org/10.5664/jcsm.1342

Alevizos, M., Karagkouni, A., Panagiotidou, S., Vasiadi, M., \& Theoharides, T. C. (2014). Stress triggers coronary mast cells leading to cardiac events. Annals of Allergy Asthma and Immunology, 112(4), 309-316. doi.org/10.1016/j.anai.2013.09.017

Alexis, O. (2010). Providing best practice in manual pulse measurement. British Journal of Nursing, 19(4), 228-234. doi.org/10.12968/bjon.2010.19.4.46784

Anwer, S., Manzar, M. D., Alghadir, A. H., Salahuddin, M., \& Abdul Hameed, U. (2020). Psychometric Analysis of the Perceived Stress Scale Among Healthy University Students. Neuropsychiatric Disease and Treatment, 16, 2389-2396. https://doi.org/ $10.2147 /$ ndt.s268582

Barbas, I., Fatouros, I. G., Douroudos, I. I., Chatzinikolaou, A., Michailidis, Y., Draganidis, D., . . . Taxildaris, K. (2011). Physiological and performance adaptations of elite Greco-Roman wrestlers during a one-day tournament. European journal of applied physiology, 111(7), 1421-1436. doi.org/ 10.1007/s00421-010-1761-7

Berg, D. D., Ruff, C. T., \& Morrow, D. A. (2021). Biomarkers for Risk Assessment in Atrial Fibrillation. Clinical Chemistry, 67(1), 87-95. doi.org/10.1093/ clinchem/hvaa298

Boisot, S., Beede, J., Isakson, S., Chiu, A., Clopton, P., Januzzi, J., . . . Fitzgerald, R. L. (2008). Serial sampling of ST2 predicts 90-day mortality following destabilized heart failure. Journal of cardiac failure, 14(9), 732-738. doi.org/10.1016/ j.cardfail.2008.06.415

Broch, K., Andreassen, A. K., Ueland, T., Michelsen, A. E., Stueflotten, W., Aukrust, P., . . Gullestad, L. (2015). Soluble ST2 reflects hemodynamic stress in non-ischemic heart failure. International journal of cardiology, 179, 378-384. doi.org/10.1016/ j.ijcard.2014.11.003

Cameli, M., Mondillo, S., Galderisi, M., Mandoli, G. E., Ballo, P., Nistri, S., . . Agricola, E. (2017). L'ecocardiografia speckle tracking: roadmap per la misurazione e l'utilizzo clinico [Speckle tracking 
echocardiography: a practical guide]. Giornale italiano di cardiologia, 18(4), 253-269. doi.org/10.1714/ 2683.27469

Cediel, G., Codina, P., Spitaleri, G., Domingo, M., Santiago-Vacas, E., Lupon, J., \& Bayes-Genis, A. (2021). Gender-Related Differences in Heart Failure Biomarkers. Frontiers in Cardiovascular Medicine, 7. doi.org/10.3389/Fcvm.2020.617705

Chen, W., Lin, A., Yu, Y., Zhang, L., Yang, G., Hu, H., \& Luo, Y. (2018). Serum Soluble ST2 as a Novel Inflammatory Marker in Acute Ischemic Stroke. Clinical Laboratory, 64(9), 1349-1356. doi.org/ 10.7754/Clin.Lab.2018.180105

Churchill,T.W., Petek, B. J., Wasfy, M. M., Guseh, J. S., Weiner, R. B., Singh, T. K., . . Baggish, A. L. (2020). Cardiac structure and function in elite female and male soccer players. JAMA Cardiology. doi.org/ 10.1001/jamacardio.2020.6088

Cohen, S. (1988). Perceived stress in a probability sample of the United States. The social psychology of health (pp. 31-67). Thousand Oaks, CA, US: Sage Publications, Inc.

Corrado, D., Basso, C., Rizzoli, G., Schiavon, M., \& Thiene, G. (2003). Does sports activity enhance the risk of sudden death in adolescents and young adults? Journal of American Colledge of Cardiology, 42(11), 19591963. doi.org/10.1016/j.jacc.2003.03.002

Demyanets, S., Kaun, C., Pentz, R., Krychtiuk, K. A., Rauscher, S., Pfaffenberger, S., . . Wojta, J. (2013). Components of the interleukin-33/ST2 system are differentially expressed and regulated in human cardiac cells and in cells of the cardiac vasculature. Journal of molecular and cellular cardiology, 60(100), 16 26. doi.org/10.1016/j.yjmcc.2013.03.020

Dickhuth, H. H., Röcker, K., Mayer, F., König, D., \& Korsten-Reck, U. (2004). [Endurance training and cardial adaptation (athlete's heart)]. Herz, 29(4), 373380. doi.org/10.1007/s00059-004-2582-4

Dieplinger, B., Januzzi, J. L., Jr., Steinmair, M., Gabriel, C., Poelz, W., Haltmayer, M., \& Mueller, T. (2009). Analytical and clinical evaluation of a novel highsensitivity assay for measurement of soluble ST2 in human plasma - the Presage ST2 assay. Clinica Chimica Acta, 409(1-2), 33-40. doi.org/10.1016/ j.cca.2009.08.010

Dill, D. B., \& Costill, D. L. (1974). Calculation of percentage changes in volumes of blood, plasma, and red cells in dehydration. Journal of Applied Physiology, 37(2), 247-248. doi.org/10.1152/ jappl.1974.37.2.247
Drawz, P. E., Beddhu, S., Kramer, H. J., Rakotz, M., Rocco, M.V., \&Whelton, P. K. (2020). Blood Pressure Measurement: A KDOQI Perspective. American Journal of Kidney Disease, 75(3), 426-434. doi.org/ 10.1053/j.ajkd.2019.08.030

Garcia, J., Muñiz, C., Rodriguez, P., \& Suarez, M. J. (2016). Comparative Analysis of Sports Practice by Types of Activities. International Journal of Sport Finance, 11(4), 327-348.

Gavrilovic, L., Spasojevic, N., \& Dronjak, S. (2012). Modulation of catecholamine-synthesizing enzymes in adrenal medulla and stellate ganglia by treadmill exercise of stressed rats. European journal of applied physiology, 112(3), 1177-1182. doi.org/10.1007/ s00421-011-2046-5

Giavarina, D., \& Lippi, G. (2017). Blood venous sample collection: Recommendations overview and a checklist to improve quality. Clinical Biochemistry, 50(10-11), 568-573. https://doi.org/10.1016/ j.clinbiochem.2017.02.021

González-Boto, R., Salguero, A., Tuero, C., GonzálezGallego, J., \& Márquez, S. (2008). Monitoring the effects of training load changes on stress and recovery in swimmers. Journal of Physiology and Biochemistry, 64(1), 19-26. doi:10.1007/bf03168231

Gustafsson, H., Sagar, S. S., \& Stenling, A. (2017). Fear of failure, psychological stress, and burnout among adolescent athletes competing in high level sport. Scandinavian Journal of Medicine and Science in Sports, 27(12), 2091-2102. doi.org/10.1111/sms. 12797

Hammadah, M., Alkhoder, A., Al Mheid, I., Wilmot, K., Isakadze, N., Abdulhadi, N., . . Quyyumi, A. A. (2017). Hemodynamic, catecholamine, vasomotor and vascular responses: Determinants of myocardial ischemia during mental stress. International Journal of Cardiology, 243, 47-53. doi.org/10.1016/ j.ijcard.2017.05.093

Hawkins, M. N., Raven, P. B., Snell, P. G., StrayGundersen, J., \& Levine, B. D. (2007). Maximal oxygen uptake as a parametric measure of cardiorespiratory capacity. Medicine and Science in Sports and Exercise, 39(1), 103-107. doi.org/10.1249/ 01.mss.0000241641.75101.64

Holfelder, B., Klotzbier, T. J., Eisele, M., \& Schott, N. (2020). Hot and Cool Executive Function in Eliteand Amateur- Adolescent Athletes From Open and Closed Skills Sports. Frontiers in Psychology, 11. doi.org/10.3389/Fpsyg.2020.00694

Howley, E.T. (2001). Type of activity: resistance, aerobic and leisure versus occupational physical activity. 
Medicine and Science in Sports and Exercise, 33(6), S364S369. doi.org/10.1097/00005768-200106001-00005

Kakkar, R., \& Lee, R.T. (2008). The IL-33/ST2 pathway: therapeutic target and novel biomarker. Nature Reviews. Drug Discovery, 7(10), 827-840. doi.org/ $10.1038 / \operatorname{nrd} 2660$

Koch, S., Cassel, M., Linné, K., Mayer, F., \& Scharhag, J. (2014). ECG and echocardiographic findings in 1015-year-old elite athletes. European Journal of Preventive Cardiology, 21(6), 774-781. doi.org/ 10.1177/2047487312462147

Kovacs, R., \& Baggish, A. L. (2016). Cardiovascular adaptation in athletes. Trends in Cardiovascular Medicine, 26(1), 46-52. doi.org/10.1016/ j.tcm.2015.04.003

Lee, E. H. (2012). Review of the psychometric evidence of the perceived stress scale. Asian Nursing Research, 6(4), 121-127. doi.org/10.1016/j.anr.2012.08.004

Lee, P., Chandel, N. S., \& Simon, M. C. (2020). Cellular adaptation to hypoxia through hypoxia inducible factors and beyond. Nature Reviews Molecular Cell Biology, 21(5), 268-283. https: / /doi.org/10.1038/ s41580-020-0227-y

Mueller,T., \& Jaffe,A. S. (2015). Soluble ST2 — analytical considerations. American Journal of Cardiology, 115 (7 Suppl), 8b-21b. doi.org/10.1016/ j.amjcard.2015.01.035

Nakamura, M., \& Sadoshima, J. (2018). Mechanisms of physiological and pathological cardiac hypertrophy. Nature Reviews Cardiology, 15(7), 387-407. doi.org/ 10.1038/s41569-018-0007-y

Ogilvie, R. P., Everson-Rose, S. A., Longstreth, W. T., Jr., Rodriguez, C. J., Diez-Roux, A. V., \& Lutsey, P. L. (2016). Psychosocial Factors and Risk of Incident Heart Failure: The Multi-Ethnic Study of Atherosclerosis. Circulation. Heart failure, 9(1), e002243-e002243. doi.org/10.1161/ CIRCHEARTFAILURE.115.002243

Pascual-Figal, D. A., \& Januzzi, J. L. (2015). The biology of ST2: the International ST2 Consensus Panel. American Journal of Cardiology, 115 (7 Suppl), 3b-7b. doi:10.1016/j.amjcard.2015.01.034

Perrone, M.A., Zaninotto, M., Masotti, S., Musetti, V., Padoan, A., Prontera, C., . . . Clerico, A. (2020). The combined measurement of high-sensitivity cardiac troponins and natriuretic peptides: a useful tool for clinicians? Journal of Cardiovascular Medicine, 21(12), 953-963. doi.org/10.2459/ Jcm.0000000000001022

Pluim, B. M., Zwinderman, A. H., van der Laarse, A.,
\& van der Wall, E. E. (2000). The athlete's heart. A meta-analysis of cardiac structure and function. Circulation, 101(3), 336-344. doi.org/10.1161/ 01.cir.101.3.336

Proietti, R., Mapelli, D., Volpe, B., Bartoletti, S., Sagone, A., Dal Bianco, L., \& Daliento, L. (2011). Mental stress and ischemic heart disease: evolving awareness of a complex association. Future Cardiology, 7(3), 425-437. doi.org/10.2217/fca.11.13

Quick, S., Waessnig, N. K., Kandler, N., Poitz, D. M., Schoen, S., Ibrahim, K., . . . Speiser, U. (2015). Soluble ST2 and myocardial fibrosis in 3T cardiac magnetic resonance. Scandinavian cardiovascular journal, 49(6), 361-366. doi.org/10.3109/ 14017431.2015 .1076936

Rafanelli, C., Roncuzzi, R., Ottolini, F., \& Rigatelli, M. (2007). Psychological factors affecting cardiologic conditions. Adv Psychosom Med, 28, 72-108. https: / / doi.org/10.1159/000106798

Santos, J. (2018). Increasing running volume elicits hematological changes in trained endurance runners: A case study. Retos, 35, 117-120.

Sarvasti, D., Lalenoh, I., Oepangat, E., Purwowiyoto, B. S., Santoso, A., \& Romdoni, R. (2020). Cardiovascular Protection Variables Based on Exercise Intensity in Stable Coronary Heart Disease Patients After Coronary Stenting: A Comparative Study. Vascular Health and Risk Management, 16, 257 270. doi.org/10.2147/Vhrm.S259190

Schnell, F. (2019). ECG in sportsmen: Distinguishing the normal from the pathological. Presse Medicale, 48(12), 1393-1400. doi.org/10.1016/ j.lpm.2019.07.008

Shah, R. V., Chen-Tournoux, A. A., Picard, M. H., van Kimmenade, R. R., \& Januzzi, J. L. (2009). Serum levels of the interleukin-1 receptor family member ST2, cardiac structure and function, and long-term mortality in patients with acute dyspnea. Circulation. Heart Failure, 2(4), 311-319. doi.org/10.1161/ circheartfailure.108.833707

Sharma, S., Drezner, J. A., Baggish, A., Papadakis, M., Wilson, M. G., Prutkin, J. M., . . Corrado, D. (2017). International Recommendations for Electrocardiographic Interpretation in Athletes. Journal of American Colledge of Cardiology, 69(8), 1057 1075. doi.org/10.1016/j.jacc.2017.01.015

Sharma, S., Merghani, A., \& Mont, L. (2015). Exercise and the heart: the good, the bad, and the ugly. European Heart Journal, 36(23), 1445-1453. doi.org/ 10.1093/eurheartj/ehv090 
Shephard, R. J. (1997). Exercise and relaxation in health promotion. Sports Medicine, 23(4), 211-217. doi.org/ 10.2165/00007256-199723040-00001

Shevchenko, N. S., Bohmat, L. F., Holovko, T. O., \& Demianenko, M. V. (2019). Adaptive capacity of the cardiovascular system in children with rheumatic diseases and comorbid conditions. Pathologia, 1(45), 99-105. https://doi.org/10.14739/23101237.2019.1.166395

Socrates, T., deFilippi, C., Reichlin, T., Twerenbold, R., Breidhardt, T., Noveanu, M., . . Mueller, C. (2010). Interleukin family member ST2 and mortality in acute dyspnoea. Journal of internal medicine, 268(5), 493-500. doi.org/10.1111/j.13652796.2010.02263.x

Steptoe, A., \& Kivimäki, M. (2012). Stress and cardiovascular disease. Natural Reviews. Cardiology, 9(6), 360-370. doi.org/10.1038/nrcardio. 2012.45

Oshikawa, K., Tominaga, S., Itoh, K., Takada, T., Suzuki, E., \& Gejyo, F. (2007). ST2 gene induced by type 2 helper T cell (Th2) and proinflammatory cytokine stimuli may modulate lung injury and fibrosis. Experimental lung research, 33(2), 81-97. doi.org/10.1080/ 01902140701198583

van de Schoor, F. R., Aengevaeren, V. L., Hopman, M.

T., Oxborough, D. L., George, K. P., Thompson, P. D., \& Eijsvogels, T. M. (2016). Myocardial Fibrosis in Athletes. Mayo Clinic Proceedings, 91(11), 1617 1631. doi.org/10.1016/j.mayocp.2016.07.012

Villarreal-Angeles, M., Rodriguez Vela, B., Tapia Martínez, R., Gallegos Sanchez, J., \& MoncadaJimenez, J. (2021). Comparison of psychological constructs in university athletes during a national competition. Retos, 42 , 618-626.

Wallentin, L., Eriksson, N., Olszowka, M., Grammer, T. B., Hagström, E., Held, C., . . . Siegbahn, A. (2021). Plasma proteins associated with cardiovascular death in patients with chronic coronary heart disease: A retrospective study. PLoS medicine, 18(1), e1003513. doi.org/10.1371/ journal.pmed. 1003513

Wan Nudri, W. D., Wan Abdul Manan, W. M., \& Mohamed Rusli, A. (2009). Body mass index and body fat status of men involved in sports, exercise, and sedentary activites. The Malaysian Journal of Medical Sciences, 16(2), 21-26.

Webb, H. E., Rosalky, D. A., McAllister, M. J., Acevedo, E. O., \& Kamimori, G. H. (2017). Aerobic fitness impacts sympathoadrenal axis responses to concurrent challenges. European journal of applied physiology, 117(2), 301-313. doi.org/10.1007/s00421016-3519-3

Weinberg, E. O., Shimpo, M., De Keulenaer, G. W., MacGillivray, C., Tominaga, S., Solomon, S. D., Rouleau, J. L., \& Lee, R. T. (2002). Expression and regulation of ST2, an interleukin-1 receptor family member, in cardiomyocytes and myocardial infarction. Circulation, 106(23), 2961-2966. doi.org/ 10.1161/01.cir.0000038705.69871.d9

Weinberg, E. O., Shimpo, M., Hurwitz, S., Tominaga, S., Rouleau, J. L., \& Lee, R. T. (2003). Identification of serum soluble ST2 receptor as a novel heart failure biomarker. Circulation, 107(5), 721-726. doi.org/ 10.1161/01.cir.0000047274.66749.fe

Wilbert-Lampen, U., Leistner, D., Greven, S., Pohl, T., Sper, S., Völker, C., . . . Steinbeck, G. (2008). Cardiovascular events during World Cup soccer. The New England journal of medicine, 358(5), 475-483. doi.org/10.1056/NEJMoa0707427

Wirtz, P. H., \& von Känel, R. (2017). Psychological Stress, Inflammation, and Coronary Heart Disease. Current Cardiology Reports, 19(11), 111. doi.org/ 10.1007/s11886-017-0919-x

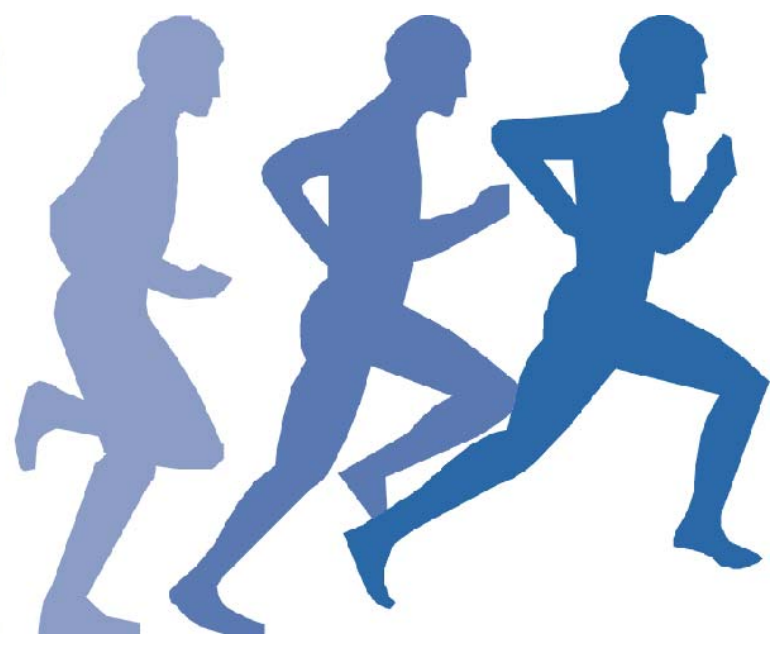

